\title{
DAS MARGENS DO MARAÚ NO BRASIL IMPERIAL À CRIAÇÃO DA PETROBRAS: 100 ANOS DE GEO-HISTÓRIA DO PETRÓLEO NACIONAL
}

\author{
FROM THE MARAÚ MARGINS IN IMPERIAL BRAZIL TO THE CREATION OF PETROBRAS: 100 YEARS OF NATIONAL OIL \\ GEO-HISTORY
}

\section{RESUMO}

O presente artigo tem como objetivo apresentar 100 anos de geo-história do petróleo brasileiro. Não trataremos aqui da descrição da "longa duração", do tempo puramente geográfico ou estrutural, pois assume-se que tal dimensão permeia e engloba de forma inexorável os demais tempos históricos, e suas respectivas imposições geográficas do meio sobre o homem ao longo de seu processo civilizatório. Como método, lastreado em Fernand Braudel e Therezinha de Castro, o presente artigo foi construído conectado ao tempo médio das conjunturas (a era do petróleo) e ao tempo curto dos fatos históricos (crises financeiras, embargos econômicos, acordos, golpes de estado, e decisões políticas). Percebeu-se, no transcorrer da pesquisa, a existência de quatro fases distintas da história do petróleo no Brasil. Fase 1: O petróleo no Brasil Imperial; fase 2: 0 petróleo: da primeira república até a sua descoberta no Brasil; fase 3: O petróleo: da criação da Petrobras até a quebra do monopólio em 1997; e fase 4: O petróleo: da quebra do monopólio da Petrobras até o pré-sal e o novo marco regulatório do setor no Brasil. São apresentadas aqui as duas primeiras fases, o petróleo no Brasil imperial e na primeira república até a criação da Petrobras.

Palavras-chave: Geo-história. Petróleo. Brasil Imperial. Brasil República. Petrobras.

\section{ABSTRACT}

This article aims to present 100 years of geo-history of Brazilian oil. We will not deal here with the description of "long duration", a geographical or structural time, as it is assumed that such dimension permeates and inexorably encompasses other historical times, and their respective geographical impositions of the environment over civilizations. As a method, backed by Fernand Braudel and Therezinha de Castro, this article was built connected to the medium time of the conjunctures (the oil era) and the short time of historical facts (financial crises, economic embargoes, agreements, coups d'état, and political decisions). It was noticed, in the course of the research, the existence of four distinct phases in the history of oil in Brazil. Phase 1: Oil in Imperial Brazil; phase 2: Oil: from the first republic until its discovery in Brazil; phase 3: Oil: from the creation of Petrobras to the breaking of the monopoly in 1997; and phase 4: Oil: from breaking Petrobras' monopoly to the pre-salt and the new regulatory framework for the sector in Brazil. Here are presented the first two phases, oil in imperial Brazil and in the first republic until the creation of Petrobras.

Keywords: Geo-history. Oil. Imperial Brazil. Brazil Republic. Petrobras.

\section{Ciro Marques Reis ${ }^{a}$}

${ }^{a}$ Universidade do Estado do Rio de Janeiro (UERJ), Rio de Janeiro, RJ, Brasil

DOI: $10.12957 /$ geouerj.2020.48493

Correpondência: ciro.reis@gmail.com

Recebido em: 17 fev. 2020 Aceito em: 26 mar.2020 


\section{INTRODUÇÃO}

A opção pela abordagem geo-histórica do tema do petróleo no Brasil, do ponto de vista metodológico, tem como objetivo relacionar o meio geográfico, as relações humanas em interação com esse meio, e por fim, o olhar próximo dos fatos políticos, econômicos e sociais ocorridos no percurso histórico vinculado ao tema. Busca-se reafirmar a importância das análises históricas e geográficas em conjunto, para compreensão das ações humanas. Analisar a disposição dessas ações humanas no espaço, segundo Braudel $(2005)^{1}$, seria o papel a ser desempenhado por uma "geografia humana inteligente", que não estaria presa à análise geográfica do presente, mas sim incorporada ao tempo, utilizando métodos geográficos para desvendar as relações humanas no transcorrer histórico.

A compreensão dos aspectos geográficos para Braudel são fundamentais, posto que estes, longe de qualquer determinismo simplório, interagem de forma coercitiva (em maior ou menor grau) com o homem através da história (RIBEIRO, 2011)². Neste aspecto, a localização geográfica das reservas de petróleo, bem como toda logística que parte desta acaba por influenciar de forma importante na história do homem a partir do final do século XX. Assume-se aqui a concepção de meio geográfico apontada por Therezinha de Castro $\left(1971\right.$, p. 13) ${ }^{3}$ como espaço vital onde se desenrola a relação homem e meio natural, abordagem especial sob o ponto de vista geopolítico. A Autora expressa ser a geo-história a melhor via para compreensão da origem da formação territorial e da construção das fronteiras atuais, sua utilização como instrumento analítico passa a ser um importante condicionante para análises geopolíticas, mesmo em período de fronteiras permeáveis, ou submetidas a fluxos multireticulares (CASTRO, 1981) ${ }^{4}$.

O presente artigo tem como objetivo construir uma geo-história do petróleo brasileiro. Não trataremos aqui da descrição da "Ionga duração", do tempo puramente geográfico ou estrutural, para recuperar o processo de divisão dos continentes, da formação das bacias sedimentares, ou da formação de hidrocarbonetos a milhões de anos nas águas profundas da costa brasileira. Assume-se que tal dimensão permeia e engloba de forma inexorável os demais tempos históricos. Ela já está presente através das imposições geográficas do meio sobre o homem ao longo de seu processo civilizatório. Como método, o presente artigo foi construído conectado ao tempo médio das conjunturas (a era do petróleo) e ao tempo curto dos fatos históricos (tais como conflitos, guerras, o sucesso exploratório de um campo de petróleo, crises financeiras, embargos econômicos, acordos, golpes de estado, e decisões políticas).

\footnotetext{
${ }^{1}$ BRAUDEL, Fernand. Escritos sobre a história. 2005

${ }^{2}$ RIBEIRO, Guilherme. Fernand Braudel e a geo-história das civilizações. História, Ciências, Saúde - Manguinhos, v.18, n.1, jan-mar, 2011, p.7-83

${ }^{4}$ CASTRO, Therezinha de. África: geo-história, geopolítica e relações internacionais. 1981
} 
Percebeu-se, no transcorrer da pesquisa, a existência de quatro fases distintas da história do petróleo no Brasil. Fase 1: O petróleo no Brasil Imperial; fase 2: O petróleo: da primeira república até a sua descoberta no Brasil; fase 3: O petróleo: da criação da Petrobras até a quebra do monopólio em 1997; e fase 4: O petróleo: da quebra do monopólio da Petrobras até o pré-sal e o novo marco regulatório do setor no Brasil. Este artigo adota como recorte temporal as duas primeiras fases, que tratam, respectivamente, do Brasil imperial e da primeira república até a descoberta de petróleo em Lobato, Bahia e seus desdobramentos até a criação da Petrobras. Em duas oportunidades inserimos breves contextualizações históricas, políticas e geográficas do petróleo no mundo.

Foram realizadas pesquisas bibliográficas e documentais. Estas últimas se mostraram particularmente importantes na reconstrução dos momentos iniciais da exploração do petróleo no Brasil. Em complemento aos livros e as legislações foram visitados jornais de época e atuais, revistas especializadas, relatórios anuais e estatísticos do Instituto Brasileiro de Geografia e Estatística (IBGE), da Agência Nacional de Petróleo (ANP), da Petrobras, da Organização para Cooperação e Desenvolvimento Econômica (OECD), da Organização dos Países Exportadores de Petróleo (OPEP), da British Petroleum, da Royal Dutch Shell, da Agência Internacional de Energia (IEA), dissertações e teses sobre o tema.

Às margens do rio Maraú: o petróleo no Brasil Imperial

Em 1892, por ordem do Governador do Estado da Bahia, Dr. Joaquim Manuel Rodrigues Lima, o Diretor do Arquivo Publico daquele Estado - Dr. Francisco Vicente Vianna - com o auxílio de José Carlos Ferreira, produziu um denso memorial do Estado da Bahia, descrevendo sua "política, geografia, a riqueza de suas indústrias, estatísticas e a doçura do clima". O documento de mais de 750 páginas, redigido em inglês, foi encomendado por ocasião da Feira Mundial de Chicago de 1893. Riquíssimo em detalhes históricos e geográficos, o memorial faz referencias aos primórdios das atividades de descoberta e de exploração de petróleo no Brasil.

[...]the discoveries of turf, petroleum and naphta, in several places of the state, have succeeded well, specially that wich was made in 1852 by Jose Francisco Thomaz do Nascimento in Marahú, where, in consequence of several authorisations and concessions granted by the government, the exploration of such substances is now advantageously carried on by the firm John Grant \& Co.(VIANNA; FERREIRA, 1893, p. 90)

As descrições do memorial vão ao encontro da literatura que trata das primeiras iniciativas de exploração de petróleo no Brasil, de personagens empreendedores como o brasileiro José Francisco Thomaz 
do Nascimento ${ }^{5}$ e o britânico John Grant $^{6}$, e da posição de vanguarda da Bahia como espaço primeiro de descoberta e de exploração de petróleo em território nacional. Debruçaram-se sobre o tema das primeiras iniciativas no campo da exploração do petróleo no Brasil, Maurício Vaitsman (O petróleo no Império e na República, 1948), Lourival Coutinho, com uma série de artigos em O Semanário em 1961 ${ }^{7}$, Pedro de Moura e Felisberto Carneiro (Em busca do petróleo brasileiro, 1976), Pedro C da Silva Telles (Antecedentes das Histórias do Petróleo e da fontes alternativas de energia no Brasil, 1986), Jucy Neiva (Conheça o petróleo, 1986), José Luciano de Mattos Dias e Maria Ana Quaglino (A questão do petróleo no Brasil, 1993), Roberto Minadeo (Um estudo de história empresarial: histórico do setor petróleo, 1998), Celso Fernando Lucchesi (Petróleo, 1998), Paulo Roberto do Santos Carvalho (O impacto da legislação ambiental na indústria de petróleo brasileira, 2001), Adalberto M Martiniano de Azevedo (Regulação ambiental e mudança técnica na indústria de refino de petróleo: o caso da refinaria de Paulínia, 2005), e Nelson Cadena (A primitiva usina de petróleo de um inglês na Bahia no século XIX, 2012), entre outros.

Com algumas exceções, os autores supracitados utilizaram como linha condutora, uma série de decretos imperiais apresentando uma descrição sequencial de autorizações, concessões, e transferências de direito de exploração e lavra de riquezas minerais do subsolo brasileiro, emitidas durante a segunda metade do século XIX. Embora haja, entre os autores citados, imprecisões e variações cronológicas sobre a primeira referencia feita à exploração de petróleo em território brasileiro sob a permissão do Império, o Decreto $\mathrm{n}^{\circ} .2 .266$, de 2 de Outubro de 1858, parece ser o primeiro a indicar tal processo no Brasil:

Decreto $n^{\circ}$. 2.266, de 2 de Outubro de 1858.

Concede a José de Barros Pimentel faculdade para por meio de huma [sic] Companhia extrahir [sic] o mineral bitunioso [sic], que denomina Bituminous Shalk [sic] próprio para o fabrico de gaz de iluminação [sic], e carvão de pedra, em terrenos situados na margem do rio Marahú [sic] da Província da Bahia. (IMPÉRIO DO BRASIL, 1858) ${ }^{8}$

\footnotetext{
5José Francisco Thomaz do Nascimento foi um engenheiro, explorador, desbravador, sertanista e minerador atuante na segunda metade do século XIX no Brasil. Firmou contratos com presidentes de províncias para exploração das riquezas do subsolo, e para desbravar os sertões de suas comarcas. Recebeu inúmeras permissões para explorar e lavrar minas de turfa, petróleo, carvão de pedra, xisto betuminoso, ouro, chumbo, sal gema, e outros minerais. Atuou nas províncias da Bahia (Comarcas de Porto Seguro e Ilhéus), Santa Catarina (Comarcas de São José e de São Miguel), e também no Paraná (explorando e pesquisando uma extensa faixa de terra entre o Rio Tibagi e as fronteiras com o Paraguai no Rio Paraná). Tais concessões, renovações de concessões e permissões estão registradas nos Decretos Imperiais №. 5.324 de 02/07/1873, №. 7.760 de 14/07/1880, №. 8.768 de 18/11/1882, №. 9.261 de 16/08/1884, No. 9.332 de 18/11/1884.

${ }^{6} \mathrm{O}$ inglês foi responsável pela construção da primeira destilaria de querosene de grande porte em território nacional (1884). A fábrica produzia velas de parafina, sabão, óleos lubrificantes,ácido sulfúrico, papel encerado, e querosene ("petróleo nacional inexplosivo [sic]"). Era um grande parque industrial baseado na extração da turfa e do xisto betuminoso. A fábrica possuía entre 350 e 500 funcionários, 30 caldeiras, 12 alambiques de 14 mil litros cada, e uma estrada de ferro interno com duas locomotivas. A pós uma greve de funcionários, e uma onda de crimes e assassinatos ligados ao movimento de paralisação a fábrica encerrou suas atividades em 1893. Problemas técnicos com a exploração da turfa podem ter auxiliado no fechamento da fábrica. (VAITSMAN, 1948; COUTINHO, 1961; TELLES, 1986; DIAS\&QUAGLINO, 1993, CADENA, 2012)

${ }^{7}$ No número 244 de O Semanário Ano V, Semana de 7 de Janeiro de 1961, página 11, Coutinho descreve uma série de concessões de explorações de petróleo e similares durante o Império e início da República e faz um breve relato sobre a fábrica de John Grant. 0 Semanário pode ser acessado em http://memoria.bn.br/DocReader/Hotpage/HotpageBN.aspx?bib=149322\&pagfis=3489\&pesq=john+grant+maraú\&url=http://memo ria.bn.br/docreader\#.

${ }^{8}$ Coleção de Leis do Império do Brasil - 1858, página 480, Vol. 1 pt II.
} 
Decretos anteriores autorizavam a extração de cobre, ouro, carvão de pedra, combustíveis fósseis e outros minerais, mas não havia alusão direta ao petróleo ou minerais betuminosos, como o xisto ${ }^{9}$. O Decreto $\mathrm{n}^{\circ}$. 2.266, de 2 de Outubro de 1858 trazia pela primeira vez, os termos "mineral betuminoso", e "xisto betuminoso", além de fazer uma clara referência ao seu uso econômico por ser "próprio para o fabrico de gaz de illuminação [sic]". O decreto dava direito a José de Barros Pimentel de explorar 60 datas (lotes) de aproximadamente 700 metros quadrados cada um, às margens do rio Maraú, na Província da Bahia, pelo prazo de 30 anos. O concessionário poderia inclusive desapropriar terrenos particulares se nestes verificasse a necessidade de mineração. Como estímulo à iniciativa, o empreendedor estava isento, pelo prazo de cinco anos, de pagar impostos relacionados à importação de maquinários e equipamentos necessários para implementação do negócio, e pelos produtos extraídos.

Em decreto exarado na mesma data e de número subsequente, 2.267, nos mesmos termos da concessão dada a Pimentel, foi concedido a Frederico Hamilton Sauthworth ${ }^{10}$ a autorização para extrair "illuminating vegetable turf" (turfa) nas margens do rio Aracahy na Bahia, também na região de Camamu.

A Comarca de Camamu na Província da Bahia, especificamente na região em torno do Rio Maraú, concentrava as solicitações iniciais de exploração de turfa, xisto betuminoso e petróleo. O rio Maraú que se estende da Baia de Camamu na direção sul, acompanhando o litoral baiano, gera uma estreita faixa de terra, dando forma à Península de Maraú. A região está localizada na Bacia Sedimentar de Camamu, rica em acumulação de hidrocarbonetos, que apresenta um litoral extremamente recortado, abundante em ilhas, com estuários e uma grande baía. A bacia é limitada ao Norte pelas Bacias de Jacuípe e do Recôncavo, e ao Sul pela Bacia de Almada (SOUZA-LIMA, 2003). Vide Figura 1.

\footnotetext{
${ }^{9}$ Um exemplo foi o Decreto no. 1.044 de 22 de Setembro de 1825 concedia a Candido Mendes d'Almeida e a Costantino Conde de Zabielo autorização para incorporar em companhia acionistas nacionais e estrangeiros, com a finalidade de explorar minas de combustíveis fósseis, de cobre, e de quaisquer outros minerais na Províncias do Maranhão e Piauí. (Coleção de Leis do Império do Brasil - 1852, página 372, Vol. 1 pt II).

${ }^{10}$ Em Setembro de 1857 o norte-americano Southworth, que residia no Rio de Janeiro, fez uma proposta de prestação de serviço publico de iluminação a gás ao Presidente da Província da Bahia, informando a utilização de um moderno aparelho produtor de gás iluminante, utilizando xisto betuminoso ou turfa. A Província da Bahia desejava se livrar da iluminação a azeite de peixe, utilizada em seus 1.500 lampiões, e substituí-la pela proposta de Southworth. Em Maio de 1858 o "Relatório da Comissão da Bahia sobre as Experiências de Frederico Southworf", designada para avaliar o funcionamento do aparelho e a qualidade de iluminação, considerou que "o gaz preparado pelo Sr. Southworth não offerece [sic] condições desfavoráveis à saúde pública, é preferível ao obtido do carvão de pedra e de uma luz muito brilhante e intensa". Não foi encontrado registro sobre o fechamento do contrato de prestação de serviço. Sobre o tema: Falla do Sr. Dezembargador J. L. V Cansansão de Sinimbú, Presidente da Província da Bahia, Abertura da Assembléia Legislativa da Bahia, setembro de 1857. Disponível em: https://archive.org/details/rpebahia1857; Correio Mercantil, Sexta-feira, 27 de Julho de 1860. p. 3. Disponível em: http://memoria.bn.br/pdf2/217280/per217280_1860_00207.pdf.
} 
Figura 1. Bacia Sedimentar de Camamu. Adap:SOUZA-LIMA ,2000. Disponível em: http://www.phoenix.org.br

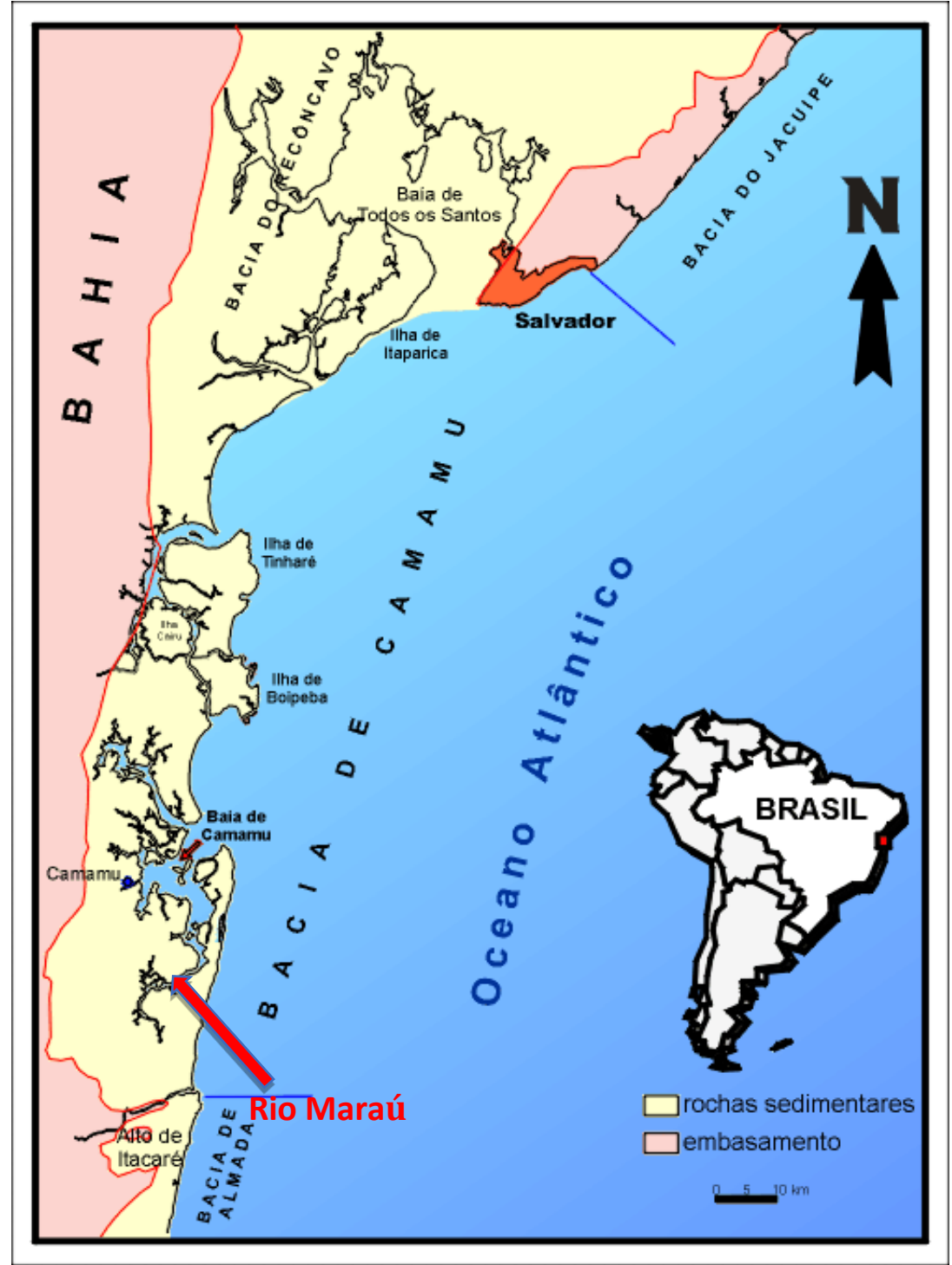

Às margens do rio Maraú, José Francisco Thomaz do Nascimento descobriu em 1852 os afloramentos de petróleo, o xisto betuminoso, e a turfa que deram início as tentativas de implementação de atividades econômicas no setor de petróleo naquela região. Outros decretos imperiais concederam autorização para exploração de minerais combustíveis (e expressamente petróleo), e transferências de direito de exploração a outros empreendedores pioneiros atraídos pelas descobertas na região. Até 1870 as iniciativas estavam circunscritas às comarcas baianas, com exceção de uma concessão para lavrar minas de xisto betuminoso no Maranhão em 1867. A partir de 1870 até o início da República, foram concedidas autorizações para explorar petróleo em comarcas de outras províncias, especialmente São Paulo. Vide Tabela 1.

No entanto, embora o petróleo cada vez mais se fizesse presente nos termos de concessões, sua importância no período do Brasil Imperial era pequena, se comparada ao protagonismo do carvão, principal 
fonte de recurso energético do período, e principal combustível gerador de calor para as máquinas a vapor, principalmente para meios de transporte como locomotivas e navios, e para a indústria em geral.

A exploração da turfa, do betume, do nafta, do xisto betuminoso, e do próprio petróleo estava ligada a sua utilização como matéria-prima para produção de lubrificantes, parafinas, graxas, e principalmente de óleos combustíveis e gases sintéticos para emprego especialmente como iluminantes. Os lampiões alimentados por azeite de peixe ou óleo de baleia importado passariam gradualmente a funcionar à base de combustíveis líquidos destilados do petróleo, como o querosene ${ }^{11}$, ou gás de iluminação proveniente da destilação da turfa e do xisto betuminoso ${ }^{12}$ por exemplo.

Tabela 1. Algumas concessões imperiais para exploração de petróleo e afins (1858-1888). Fonte: O Autor, 2014. Adaptado de Coleção de Leis do Império do Brasil (1854-1890); 1 - CARVALHO (2001. p.79); 2 - TELLES (1986, p. 255)

\begin{tabular}{|c|c|c|c|}
\hline Decreto & Ano & Beneficiário & Finalidade/Local/Tempo \\
\hline No. 2.266 & 1858 & José Barros Pimentel & $\begin{array}{l}\text { Mineral betuminoso (Bituminous shalk [sic], e carvão de } \\
\text { pedra/margens do rio Maraú, Bahia/30 anos }\end{array}$ \\
\hline No. 2.267 & 1858 & Frederico Hamilton Sauthworth & $\begin{array}{l}\text { Mineral denominado Illuminating vegetable turf/margens } \\
\text { do rio Maraú, Bahia/30 anos }\end{array}$ \\
\hline No. $3.352^{\mathrm{A}}$ & 1864 & Thomaz Denny Sargent & $\begin{array}{l}\text { Turfa, petróleo e outros minerais/Comarcas de Camamu e } \\
\text { Ilhéus, Bahia/90 anos }\end{array}$ \\
\hline No. 3.457 & 1865 & Thomaz Denny Sargent & $\begin{array}{c}\text { Elevação de datas minerais de } 30 \text { para } 60 \text { conforme } \\
\text { Decreto 3.352A/ Comarcas de Camamu e llhéus, Bahia/90 } \\
\text { anos }\end{array}$ \\
\hline No. 3.564 & 1865 & Thomaz Denny Sargent & $\begin{array}{c}\text { Altera condições relativas a prazos de execução das } \\
\text { atividades previstos no Decreto } 3.352 \mathrm{~A} / \text { Comarcas de } \\
\text { Camamu e llhéus, Bahia/90 anos }\end{array}$ \\
\hline No. 3.804 & 1867 & $\begin{array}{l}\text { Polycarpo Lopes de Leão; } \\
\text { Nathaniel Plant }\end{array}$ & $\begin{array}{l}\text { Minas de xisto betuminoso e outros minerais/Comarcas da } \\
\text { Capital, Rosário, Vianna e Alto Mearim, Maranhão/3 anos }\end{array}$ \\
\hline No. 4.386 & 1869 & Eduardo Pellew Wilson & $\begin{array}{l}\text { Carvão de pedra, turfa e outros minerais/margens do rio } \\
\qquad \text { Maraú, Bahia/30 anos }\end{array}$ \\
\hline No. 4.457 & 1870 & Eduardo Pellew Wilson & $\begin{array}{l}\text { Altera a concessão } 4.386 \text { de 30/06/1869 excluindo a lavra } \\
\text { do carvão de pedra, e aumentando de } 30 \text { para } 90 \text { anos o } \\
\text { período de concessão/margens do rio Maraú/90 anos }\end{array}$ \\
\hline No. 4.725 & 1871 & $\begin{array}{l}\text { Angelo Thomaz do Amaral; } \\
\text { Antonio Candido da Rocha }\end{array}$ & $\begin{array}{c}\text { Chumbo, petróleo e minerais, exceto diamantes/Freguesia } \\
\text { de Iporanga, Município de Xiririca, São Paulo/2 anos }\end{array}$ \\
\hline No. 5.014 & 1872 & Luiz Matheus Mayalaski & $\begin{array}{l}\text { Minas de carvão de pedra e petróleo/Comarcas de } \\
\text { Sorocaba, Itapetininga e Itú, São Paulo/2 anos }\end{array}$ \\
\hline No. 5.050 & 1872 & $\begin{array}{c}\text { Cyrino Antônio de Lemos; João } \\
\text { [sic]Baptista da Silva Gomes } \\
\text { Barata }\end{array}$ & $\begin{array}{c}\text { Minas de carvão de pedra e petróleo/Comarca da Capital, } \\
\text { São Paulo/2 anos }\end{array}$ \\
\hline No. 5.115 & 1872 & Luiz Antônio de Souza Barros & $\begin{array}{c}\text { Minas de xisto betuminoso e querosene, de carvão de } \\
\text { pedra e outros minerais/Fazenda S. Lourenço, São Paulo/3 } \\
\text { anos }\end{array}$ \\
\hline
\end{tabular}

${ }^{11}$ No Decreto Imperial no. 7.980 de 1881, foi concedida a Antonio Lopes Carneiro a autorização para trabalhar, no prazo de 10 anos, na invenção de um processo químico que torna-se o querosene não explosivo, dado o interesse em seu emprego como iluminante, e sua reconhecida instabilidade química que o tornava altamente explosivo. A Fábrica de John Grant em Maraú produzia querosene proveniente da destilação da turfa, o óleo era chamado de Brazolina "petróleo nacional inexplosivo". Foi a única fábrica no período imperial brasileiro a produzir combustível líquido. (Telles, 1986. p. 254)

${ }^{12}$ No dia 7 de Setembro de 1883, foi criada em Taubaté, São Paulo a Companhia de Gás e Óleos Minerais. A fábrica iluminou a cidade de Taubaté durante 15 anos, utilizando o xisto, de rica presença na região, como fonte para produção de gás. Todos os equipamentos para montagem da infraestrutura da companhia foi importado, inclusive seus primeiros gerentes ingleses. Ver Maria Cristina Martínez Soto. Pobreza e Conflito: Taubaté 1860-1935. A usina foi desativada em 1897, por problemas técnicos. Além de gás, produzia querosene, graxas e parafinas (Moura e Carneiro apud Dias e Quaglino (1993). p. 45) 


\begin{tabular}{|c|c|c|c|}
\hline No. 5.324 & 1873 & $\begin{array}{l}\text { José Francisco Thomaz do } \\
\text { Nascimento }\end{array}$ & $\begin{array}{l}\text { Turfa, carvão de pedra e xisto betuminoso/terras de sua } \\
\text { propriedade, Comarcas: Porto Seguro e Ilhéus, Bahia/5 } \\
\text { anos. }\end{array}$ \\
\hline No. 5.732 & 1874 & $\begin{array}{l}\text { Cyrino Antônio de Lemos; José } \\
\text { [sic]Baptista da Silva Gomes } \\
\text { Barata }\end{array}$ & $\begin{array}{c}\text { Prorrogação por mais um ano para concessão referente ao } \\
\text { Decreto no. } 5.050 \text { de } 14 / 08 / 1872 .\end{array}$ \\
\hline No. 5.874 & 1875 & $\begin{array}{l}\text { Antônio Candido da Rocha; } \\
\text { Domingos Moutinho }\end{array}$ & $\begin{array}{l}\text { Concessão de } 50 \text { datas minerais e } 50 \text { anos para lavra de } \\
\text { chumbo, petróleo, e quaisquer minerais, exceto diamantes } \\
\text { (altera Decreto no. } 4725 \text { de } 09 / 05 / 1871 \text { ) }\end{array}$ \\
\hline No. 6.216 & 1876 & Eduardo Pellew Wilson & $\begin{array}{l}\text { Minerais combustíveis/municípios de Cayrú e Taperoá, } \\
\text { Comarca de Valença, Bahia/50 anos }\end{array}$ \\
\hline No. 7980 & 1881 & Antonio Lopes Cardoso & $\begin{array}{l}\text { Privilégio de } 10 \text { anos para processo químico de sua } \\
\text { invenção, com a qual torna inexplosivo [sic] o querosene. }\end{array}$ \\
\hline No. $8.365^{1}$ & 1881 & $\begin{array}{l}\text { Domingos Moutinho; José } \\
\text { Rodolpho Monteiro; Robert } \\
\text { Normanton; William Burnett }\end{array}$ & $\begin{array}{c}\text { Combustíveis minerais (xisto)/ Vale do Paraíba, São Paulo/ } \\
\text { - }\end{array}$ \\
\hline No. 8.826 & 1882 & $\begin{array}{l}\text { João Chrysostomo do Amaral } \\
\text { Brisola }\end{array}$ & $\begin{array}{c}\text { Explorar minerais, minas de carvão, "asfalto, petróleo e } \\
\text { nafta" } 2 / \text { São Paulo/Itapetininga, São Paulo/- }\end{array}$ \\
\hline No. 9.328 & 1884 & $\begin{array}{l}\text { John Camaron Grant; Lord } \\
\text { Walsingham }\end{array}$ & $\begin{array}{c}\text { Transferência de concessão (Decreto } 4.366 \text { de } 30 \text { de Junho } \\
\text { de } 1869 \text {, e } 4.457 \text { de } 21 \text { de Janeiro de } 1870 \text { ) de Eduardo } \\
\text { Pellew para John Grant e Lord Walsingham/margens do rio } \\
\text { Maraú, Bahia }\end{array}$ \\
\hline No. 10.073 & 1888 & Tito Lívio Martins & Petróleo e outros minerais/Tatuhy, São Paulo/1 ano \\
\hline
\end{tabular}

Foi característica do período imperial brasileiro a exploração de fontes de petróleo ou afins disponíveis em afloramentos naturais, às margens de rios, em mangues, minando de pedras, sem uma maior necessidade de investigação mais profunda do subsolo para a sua descoberta e inicial exploração. Do ponto de vista econômico sua importância era local, dinamizando algumas cidades através da iluminação pública. Geograficamente esteve concentrada no litoral baiano, apresentando ao final do Império o crescimento das explorações em São Paulo, no Vale do Paraíba, acompanhando o desenvolvimento industrial da região que recebia o capital excedente da lavoura cafeeira, e que iniciava a diversificação de sua economia com surgimento das primeiras indústrias, num quadro de crescimento urbano, e de expansão das estradas de ferro.

O setor foi regulado por decretos imperiais, e dependeu da iniciativa de empreendedores privados, em especial ingleses, que já atuavam na exploração econômica do carvão e no negócio de ferrovias no Brasil. Resultando em poucas e breves experiências comerciais e industriais, sobretudo pela necessidade de se importar praticamente tudo - de maquinários à mão de obra especializada - a fase imperial da história do petróleo no Brasil chegava ao seu fim sem que o negócio do petróleo deixasse de ser local e sem nenhuma expressão do ponto de vista geopolítico e comercial em termos internacionais. O Brasil estava à margem do comércio e da indústria que estava prestes a revolucionar o mundo.

Quando finda o império brasileiro em 1889, já havia se passado 30 anos desde que o primeiro poço de petróleo, comercialmente viável, fora perfurado com sucesso por Edwin L. Drake em 1859 em Titusville, no estado norte-americano da Pensilvânia. O negócio do petróleo no mundo, e especificamente o comércio de querosene para iluminação já estava em franca expansão. A Standard Oil of Company criada em janeiro de 
1870, já em 1890 possuía quase um monopólio perfeito, com aproximadamente 85\% do negócio do petróleo norte-americano, dominando produção, transporte, refino e distribuição (YERGEN, 2012).

Sumatra nas Índias Orientais Holandesas (berço da então nascente Royal Dutch), e o eixo Baku-Batum, que interligavam o Mar Cáspio e o Mar Negro no Império Russo (atuais Azerbaijão e Geórgia, respectivamente), constituíam-se em importantes centros de produção e distribuição de petróleo respectivamente. A rede de comércio de petróleo já fazia uso de espaços marítimos, ainda hoje consagrados, para o seu transporte, interligando os mares Arábico, Vermelho, Negro, Cáspio, Mediterrâneo e o Mar do Norte - abastecendo o mercado asiático e europeu com querosene - além das rotas do Atlântico Norte (EUAEuropa), e do Atlântico Sul, contornando a África Austral (EUA-Ásia).

Do ponto de vista geoestratégico, além do Atlântico, o Estreito de Bósforo e o Canal de Suez representavam os pontos sensíveis e vitais na rota comercial do petróleo ao final do século XIX. O primeiro interligando o Mar Negro ao Mar de Mármara e o Mediterrâneo, proporcionava o escoar da produção petrolífera da Rússia concentrada na região do Mar Cáspio, e o segundo conectando o Mar Vermelho ao Mediterrâneo possibilitando a entrada da produção de petróleo oriunda das Índias Orientais Holandesas. 0 Golfo Pérsico e o Estreito de Ormuz ainda não figuravam como áreas estratégicas neste período.

Dois outros grandes players do período atuavam através do petróleo russo: os Nobel ${ }^{13}$ que controlavam o mercado interno russo, e os Rotschild que investiam na direção do oeste europeu e em mercados periféricos na área de influência da Standard Oil, como a Ásia (YERGEN, 2012).

Em 1883 a ferrovia Baku-Batum, financiada pelos Rotschild ${ }^{14}$, abria definitivamente o mercado europeu ao petróleo russo, através de fretes competitivos, que faziam frente aos estabelecidos no comercio Estados Unidos - Europa (COTTA, 1975). Na Ásia, a associação entre os Rotschild e o comerciante Marcus Samuel (fundador da Shell) possibilitou a implementação de uma grande rede de transporte e estocagem e distribuição de querosene, além de resultar na primeira utilização do Canal de Suez para travessia de naviostanque carregados de petróleo e querosene em cinco de Janeiro de 1892. Em Sumatra, a Royal Dutch iniciava suas atividades no setor petrolífero. Em poucos anos a empresa se uniria a Shell, dando origem em 1907 à gigante Royal Dutch Shell. A formação de grandes trustes como a Standard Oil e a Royal Dutch Shell era característico do período do capitalismo monopolista-financeiro ao final do século XIX.

\footnotetext{
${ }^{13} \mathrm{Em}$ 1873, o czar concedeu direitos de exploração e exportação de petróleo aos irmãos Nobel na região de Baku (ver Pery Cotta. 0 Petróleo é nosso? 1975, p. 183).

${ }^{14} \mathrm{O}$ ramos francês dos Rotschilds que já investiam principalmente em ferrovias em todo mundo, possuíam uma refinaria no Mar Adriático, o que fez o interesse pelo petróleo russo uma consequente oportunidade de negócio, dada a explosão da produção das reservas de Baku.
} 
O querosene era o principal produto da indústria de petróleo, mas algumas inovações tecnológicas e decisões políticas alterariam esse quadro no início do século XX. A luz elétrica e o motor à combustão associadas à gradual substituição do carvão pelo petróleo como combustível para navios, e à crescente utilização da gasolina para nascente indústria automobilística alterariam o grau de protagonismo entre os derivados do petróleo. Em 1900, a produção mundial de petróleo girava em torno de 150 milhões de barris por ano.

De Bofete a Lobato: existe petróleo no Brasil!

Somente em 1892, já no período republicano, foi realizada a primeira sondagem profunda em território nacional, em Bofete, São Paulo. Eugênio Ferreira de Camargo, com ajuda de um engenheiro belga e sondadores americanos ${ }^{15}$, perfurou 488 metros, retirando apenas dois barris de petróleo (TELLES, 1986; DIAS \& QUAGLINO, 1993). É neste momento, porém, o início do período republicano no Brasil, que segundo Maurício Vaitsman, as atividades de mineração entram em um período de estagnação:

\begin{abstract}
“O regime legal de minas, com o incentivo aos pioneiros, e o aprimoramento dos estudos geológicos e mineralógicos, a par de fatôres [sic] de ordem econômica e outros, deram à mineração uma posição destacada dentre as atividades nacionais no três últimos decênios do império [...] O número de interessados na exploração de combustíveis minerais, sobretudo o petróleo, ia crescendo, quando sobreveio a República, que fez cessar bruscamente os pedidos de concessão para a exploração..." (VAITSMAN, 1948, p. 49)
\end{abstract}

Dois fatores concorreriam para desestimular e dificultar as atividades de mineração de uma forma geral, e consequentemente refrear o crescente interesse pela exploração de petróleo: os artigos 64 e 72 da Constituição Republicana de 1891. Se no período imperial a riqueza do subsolo estava dissociada da propriedade da terra, podendo até mesmo o dono da concessão de exploração de minas desapropriar os terrenos onde estivesse constatada a existência de recursos economicamente exploráveis, na nova Constituição o proprietário da terra tornava-se também o dono do subsolo ${ }^{16}$. A União também passava aos Estados a responsabilidade de legislar sobre as minas ${ }^{17}$.

Dias \& Quaglino (1993) perpassam pelos conflitos entre proprietários de terra e exploradores de minas, sobre a questão da propriedade e de toda a riqueza que nela se encerra. O Aviso no. 53 do Ministério da

\footnotetext{
${ }^{15} \mathrm{O}$ cientista belga Auguste Collon analisou as possibilidades de obtenção de petróleo. O responsável pela perfuração foi o norteamericano Artur Reardon.

${ }^{16} \mathrm{Art} .72 \S 17$ - $\mathrm{O}$ direito de propriedade mantém-se em toda a sua plenitude, salva a desapropriação por necessidade ou utilidade pública. As minas pertencem aos proprietários do solo, salvas as limitações que forem estabelecidas por lei a bem da exploração deste ramo de indústria (Constituição da República do Estados Unidos do Brasil de 1891)

${ }^{17}$ Art. 64 - Pertencem aos Estados as minas e terras devolutas situadas nos seus respectivos territórios, cabendo à União somente a possessão de território que for indispensável para a defesa das fronteiras, fortificações, construções militares e estradas de ferro federais. (Constituição da República do Estados Unidos do Brasil de 1891)
} 
Agricultura, Comércio e Obras Públicas de sete de fevereiro de $1871^{18}$ havia surgido como resposta para tais desavenças. Confirmava os termos dos decretos imperiais exarados, reafirmando ser de propriedade do Estado todo e qualquer deposito mineral do território, negando aos proprietários dos terrenos a propriedade da riqueza de seu subsolo. A Constituição de 1891 revogou tais princípios.

Na mesma linha de raciocínio de Vaistman, Dias \& Quaglino reconhecem na legislação liberal de 1891 decisões prejudiciais às atividades de exploração de petróleo no Brasil.

\begin{abstract}
"As consequências efetivas dessa ampla desregulação mostraram-se no entanto, com o passar do tempo, bastante prejudiciais à atividade mineira. O vincula entre a propriedade do solo e a do subsolo, por exemplo, teve o efeito de incluir as jazidas minerais nas infinitas querelas que envolviam tradicionalmente a propriedade de terras no Brasil: disputa entre herdeiros, incertezas quanto ao título de posse ou conflito de limites. [...] Dispondo agora de amparo legal, a tendência com o tempo, foi a de negar qualquer acesso à propriedade. Investir em mineração tornava-se, desse modo, uma atividade cercada de incertezas legais." (DIAS\&QUAGLINO, 1993, p. 7-8)
\end{abstract}

Somente com a criação do Serviço Geológico e Mineralógico do Brasil em 1907, uma certa sistematização dos processos investigativos em mineração foi iniciado em território nacional. Fora convidado para presidir o SGMB, o geólogo e geógrafo norte-americano Orville Derby ${ }^{19}$. Seria um período de significativo aumento das perfurações de poços em "bases mais profissionais" (MILANI, et al., 2001; LUCCHESI, 1998), principalmente a partir de 1919, quando os eventos da Grande Guerra havia deixado claro a importância estratégica do petróleo para a segurança das nações. A Lei Calógeras ${ }^{20}$ de 6 de janeiro de 1915 também abria espaço para diminuir e relativizar o poder dos proprietários de terra sobre as riquezas do subsolo, herança deixada pela Constituição Republicana de 1891.

Entre 1919 e 1930, o SGMB realizou 51 perfurações à procura de petróleo nos estados do Paraná, São Paulo, Rio Grande do Sul, Santa Catarina, Bahia, Alagoas, e no Pará, concentrando mais de um terço dessas explorações em São Paulo.

\footnotetext{
${ }^{18} \mathrm{O}$ Aviso Imperial firmava princípios sobre as descobertas de minas e sua relação com a propriedade da terra, além de equiparar ao carvão de pedra, petróleo, xisto betuminoso e outros semelhantes aos outros metais preciosos. O caso específico relatava as reclamações dos proprietários de terra João da Costa Junior e Antônio Martins da Silva que alegavam que a concessão dada ao britânico Eduardo Pellew Wilson abrangia suas terras. A decisão manteve a concessão ao britânico alegando que os proprietários da terra não haviam recebido autorização do Governo Imperial para extração de minerais, que era de interesse do Império estimular empreendedores ativos e atrair capitais para estimular a mineração. (Aviso no. 53 - Agricultura, Commercio e Obras Públicas - em 7 de Fevereiro de 1871. Coleção das Leis da República Federativa do Brasil, 1872 p. 41-42)

${ }^{19}$ Derby havia participado da equipe do geólogo Charles F Hart, que presidiu a Comissão Geológica do Império, criada por D. Pedro II em 1875 e que durou apenas até 1875. Posteriormente seria convidado para presidir em 1886 a Comissão Geográfica e Geológica da Província de São Paulo.

${ }^{20}$ Decreto no. 2.933, de 6 de Janeiro de 1915 que regula a propriedade de minas. Entre os artigos, destaca-se o Art. 17: Se o proprietário do solo recusar seu consentimento para que se efetuem pesquisas em suas terras, fica reconhecido ao pretendente à pesquisa o direito de desapropriar as terras na forma da legislação vigente. (Diário Oficial da União - Seção 1 - 7/1/1915, p. 297)
} 
Figura 2. Número de perfurações (SGMB) por estados (1919-1930). Fonte:O Autor, 2014 adaptado de DIAS e QUAGLINO, 1993 , p. 13.

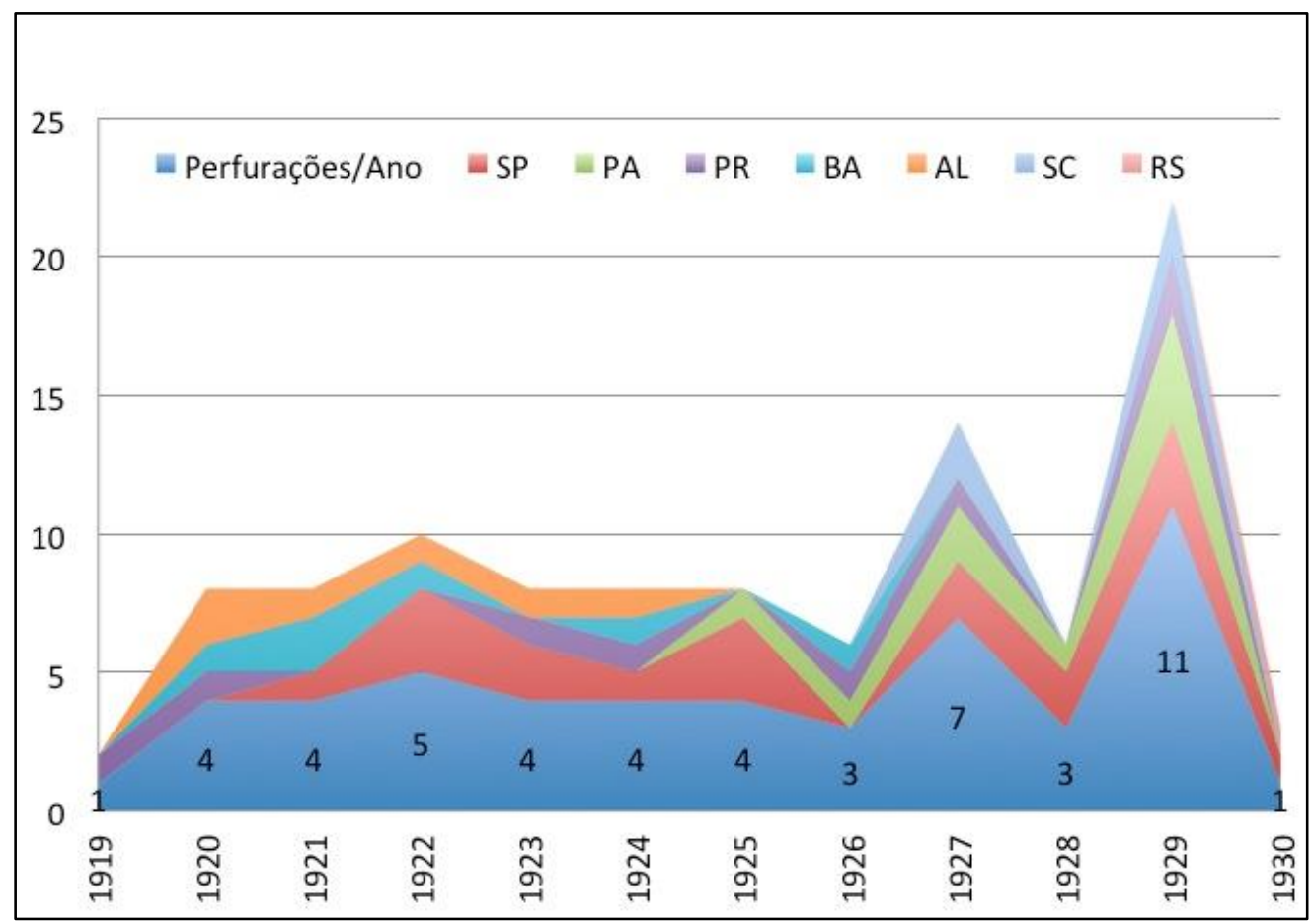

As poucas realizações do $\mathrm{SGMB}$, no que tange a dinamizar a indústria petrolífera nacional, à despeito de sua importância como base de conhecimento acumulado (DIAS e QUAGLINO, 1993), encontrariam no Governo Provisório de Vargas seu findar. Em 1933 é criada a Diretoria Geral de Pesquisas Científicas, subordinada ao SGMB, e o Instituto Geológico e Mineralógico do Brasil que ocuparia muito brevemente o lugar do SGMB. Em 1934 em meio a reforma administrativa do Governo Provisório é criado o DNPM Departamento Nacional de Pesquisa Mineral, extinguindo-se a Diretoria Geral de Pesquisas Científicas. O DNPM passa a ser o órgão encarregado pela aplicação e controle do novo Código de Minas (inclusive petróleo), decretado poucos meses mais tarde, em julho de 1934. Definitivamente separava-se a propriedade do solo, da do subsolo ${ }^{21}$.

Todas as alterações e ajustes constitucionais tratavam das atividades de mineração, não especificamente de petróleo. Mas em 1938 foi incorporado ao Código de Minas de 1934, um título específico instituindo o "Regime Legal das Jazidas de Petróleo e Gases Naturais ${ }^{22}$. No rastro das mudanças regulatórias e do crescente reconhecimento do valor estratégico do petróleo em tempos de afirmações nacionalistas, o

\footnotetext{
${ }^{21}$ O Decreto No. 24.642 de 10 de Julho de 1934 que tratava do novo Código de Minas, em seu capítulo segundo que tratava das propriedade das jazidas e minas, em seu Artigo 4º sentenciava: "[...] Assim a propriedade da superfície abrangerá a do subsolo na forma de direito comum, excetuadas, porém, as substância minerais ou fósseis uteis à indústria.". A Constituição de 1937 e o Código de Minas de 1940 mantiveram a mesma posição, sem maiores alterações sobre o tema. Sobre os aspectos legais e constitucionais relacionados com a dissociação da propriedade do solo e do subsolo ver Carlos Luiz Ribeiro. Tratado de Direito Minerário. Belo Horizonte: Del Rey, 2005, p. 10

22Decreto-Lei no 366, de 11 de Abril de 1938. Disponível em: http://www.planalto.gov.br/ccivil_03/Decreto-Lei/19371946/Del0366.htm
} 
mesmo decreto submetia os contratos de concessão ao escrutínio do Conselho Superior de Segurança Nacional.

\begin{abstract}
Art. 96 A lei não reconhece o domínio privado de particulares, como já instituído, sobre jazidas de petróleo e gases naturais, pelo fato de não ter sido descoberta nenhuma jazida desta classe suscetível de utilização industrial, enquanto vigorou o direito de acessão da propriedade do solo sobre as minas. [...] Parágrafo Único: Poderá, outrossim mediante parecer favorável do Conselho Superior de Segurança Nacional, contratar com empresas especialistas, de reconhecida idoneidade técnica e financeira, nacionais ou estrangeiras, a perfuração de poços para pesquisa e extração de petróleo, correndo por conta e risco das empresas contratantes todas as despesas a serem efetuadas, contra uma participação, que for convencionada, nos produtos da exploração.
\end{abstract}

(BRASIL, 1938)

A questão do petróleo em si, como insumo estratégico para economia e segurança nacional, seria melhor definida a partir da criação, através do Decreto-Lei nº 395 de 29 de abril de 1938, do Conselho Nacional de Petróleo (CNP). A própria composição do CNP já era um indicativo dos múltiplos interesses setoriais em torno do petróleo e de sua importância estratégica. Somente brasileiros natos poderiam fazer parte do Conselho, que, além do Presidente da República, contava com representantes dos Ministérios da Guerra, Marinha, Fazenda, Agricultura, Viação e Obras Públicas, Trabalho, Indústria e Comércio, assim como as organizações de classe da Indústria e do Comércio. Composição que seguia as determinações do Decreto-Lei $\mathrm{n}^{\circ} .538$ de 7 de julho de 1938 que organizava e definia as atribuições do CNP.

Durante as décadas de 1920 e 1930 a importância e a necessidade de se produzir petróleo em território nacional já era discutida sob o ponto de vista não só econômico, mas também geopolítico, contrapondo os projetos nacionais de desenvolvimento industrial aos interesses das grandes companhias de petróleo estrangeiras que já se faziam presentes no Brasil, como a norte-americana Standard Oil Company e a angloholandesa Royal Dutch Shell ${ }^{23}$.

Havia grande debate sobre a existência ou não petróleo no Brasil, e sobre o alinhamento político internacional das classes dirigentes nacionais pela opção norte-americana ou alemã. Vargas se equilibrava entre as pressões de liberais alinhados com o pan-americanismo, e nacionalistas que tendiam à aproximação política, econômica e ideológica com a Alemanha, em particular os militares. O pragmatismo foi a opção brasileira nas relações internacionais, fazendo o jogo pendular e equidistante entre as duas potências do período.

Os gastos com importação de produtos industrializados era crescente e os ganhos com a exportação de café declinavam. O projeto de industrialização e modernização do Brasil, fosse a bases nacionalistas

\footnotetext{
${ }^{23}$ Através do decreto $n^{\circ}$. 9.335, de 17 de janeiro de 1912, a Standard Oil recebe permissão para continuar funcionando no Brasil, através da Standard Oil Company of Brazil, nova denominação da Empreza [sic] Industrial de Petróleo, que já atuava desde 1897 no Brasil (decreto n. 2.471, de 8 de março de 1897). Um ano mais tarde, através do Decreto no. 10.168, de 9 de abril de 1913, seria a vez do truste concorrente, a Royal Dutch Shell chegar ao Brasil, através da Anglo Mexican Petroleum Productos Company (somente em 1946 a empresa passaria a adotar a sua denominação Shell no Brasil).
} 
estatizantes, fosse a bases liberais, era uma aspiração nacional, e o petróleo e a siderurgia eram vistos como elementos chaves desse processo para a implementação de uma indústria moderna no Brasil. A Companhia Siderúrgica Nacional (CSN) e a Companhia Vale do Rio Doce, fundadas respectivamente em 1941 e 1942 , seriam resultantes do pragmatismo brasileiro na política externa durante a Segunda Guerra Mundial ${ }^{24}$. Mas mesmo com todas as alterações constitucionais e decretos-lei destinados especificamente a tratar da produção e distribuição do petróleo no Brasil, uma questão permanecia como um problema central: os anos 30 já estavam se encerrando, sem que fosse encontrado petróleo comercialmente viável no território nacional. E o ingresso para quadro das grandes nações do mundo condicionava-se cada vez mais pela produção e controle do petróleo.

O DNPM permanecia com seus trabalhos exploratórios em várias regiões do Brasil 25 , até que, em 1939, um ano após a criação do CNP foi encontrado petróleo em Lobato, na Bahia.

\begin{abstract}
O PETRÓLEO EM LOBATO, NO ESTADO DA BAHIA
Interessantes informações prestadas pelo Gabinete do Sr. Ministro da Agricultura.

O Gabinete do Sr. Fernando Costa, Ministro da Agricultura, forneceu hontem [sic], à imprensa as seguintes notas:

OCORRÊNCIAS DOS DIAS 21 E 23 DE JANEIRO DE 1939

A existência de petróleo em Lobato, Estado da Bahia, acaba de ser constatada pelo engenheiro Custódio Braga Filho, encarregado da sondagem n. 163 da Divisão de Fomento da Produção Mineral [...] Segundo telegrama desse engenheiro [...] começaram a partir do dia 21, a aparecer gotinhas de óleo. Acentuouse o fenômeno no dia seguinte até que, a 23, a sondagem atingiu o nível em que a pressão estática do óleo permitiu a sua saída até a boca do poço. Finalmente, no dia de hoje, 24, [...] a quantidade de óleo, que subiu ao poço foi suficiente para permitir uma colheita de setenta litros desse material.

(JORNAL DO BRASIL, quarta-feira, 25/01/1939, p.7)
\end{abstract}

O CNP, em julho de 1939 assume as atividades até então executadas pelo DNPM, inclusive herdando seu quadro técnico. As perfurações na área de Lobato foram intensificadas, mas se mostrariam em pouco tempo subcomerciais ${ }^{26}$, no entanto o mapeamento geológico do Recôncavo não deixava dúvidas sobre o potencial petrolífero da região. O CNP passou a direcionar recursos para exploração na área do Recôncavo baiano, e em novembro de 1941 foi encontrada a primeira acumulação comercialmente viável do Brasil, em Candeias.

\footnotetext{
${ }^{24}$ Fruto do alinhamento Brasil-EUA em virtude do contexto da Segunda Guerra Mundial. De um lado, os norte-americanos receberiam suprimentos estratégicos de matéria-prima e evitaram a aproximação comercial da Alemanha com o Brasil, e por outro lado o Brasil iniciaria as bases de implementação do seu processo de industrialização.

${ }^{25} \mathrm{~A}$ divisão territorial do Brasil no que tange as áreas de pesquisa de regiões petrolíferas estava organizada em 5 regiões pelo DNPM: 1 - NORDESTE - faixa litorânea de Natal à Maraú na Bahia, incluindo partes do Rio Grande do Norte, Paraíba, Pernambuco, Alagoas, Sergipe, Bahia e Espírito Santo; 2 - ACRE - Território do Acre e parte do Amazonas; 3 - GONDWANA - São Paulo, Minas Gerais, Goiás, Mato Grosso, Paraná, Santa Catarina, e Rio Grande do Sul; 4 - BAIXO AMAZONAS - Parte do Amazonas e Pará; e 5 - MEIO NORTE - Parte do Piauí e Maranhão. Fonte: Revista da Sociedade de Geografia do Rio de Janeiro, Tomo XLVIII - 1941. Capítulo: Fenômenos Econômicos e Petróleo. Autor: Coronel Temístocles de Sousa Brasil p.23. Disponível em: http://memoria.bn.br/DocReader/docreader.aspx?bib=181897\&pasta=ano\%20194\&pesq=petróleo ${ }^{26}$ Foram 4 anos de atividade em Lobato, sendo perfurados 17 poços (7 com óleo e 10 secos). Segundo DIAS e QUAGLINO (1993), apesar dos primeiros indícios de pouca capacidade produtiva dos primeiros do campo de Lobato, abandonar a atividade de exploração no local estava fora de cogitação, dada toda expectativa gerada pela imprensa e às pressões sobre o poder público que se acaloravam em virtude do debate sobre o petróleo que se adensava no Brasil.
} 
Nos 10 anos seguintes a Bacia do Recôncavo concentraria de forma significativa as atividades de perfuração no país. Entre 1939 e 1949, das 188 perfurações realizadas pelo CNP²7, 172 localizavam-se no Recôncavo baiano, além dos campos de Lobato e Candeias, foram abertos os campos de exploração de Itaparica, Aratu, Camaçari, Mata de São João, Remanso, Dom João, e Pitanga. As demais bacias onde foram realizadas perfurações no período, foram: Sergipe (12), Alagoas (7), Tucano Sul (3), Camamu (2), Tucano Norte (1), e Tucano Central (1). Era a afirmação das projeções do DNPM sobre a existência da província petrolífera do Nordeste, a principal entre as cinco regiões exploratórias sobre as quais foram dispersos os esforços de exploração e pesquisa de petróleo no período. Amplo destaque para as perfurações realizadas na Bahia, com poucas incursões em Alagoas e Sergipe.

De fato, a ainda incipiente produção petrolífera brasileira no período esteve restrita à Bahia e à região do Recôncavo especialmente, que produzia em 1951 aproximadamente 90 mil toneladas de petróleo. Números insignificantes se comparados a crescente demanda interna por óleos combustíveis. Estava claro que a despeito do aumento das perfurações, não houvera aumento expressivo da produção de petróleo nacional no período.

A explosão do consumo de derivados de petróleo no Brasil no início dos anos 50 acabou por gerar uma maior dependência da importação de óleos combustíveis. Entre 1939 e 1952 a importação de óleos combustíveis (gasolina e diesel) aumentou em 370\% passando de pouco mais de 678 mil toneladas em 1938 para mais de 3 milhões de toneladas em 1952. Antilhas Holandesas e Venezuela eram os principais fornecedores destes derivados para o Brasil que também importava uma terceira e complementar parte de Trinidad. Quase todo óleo refinado lubrificante era importado dos EUA e seu volume de importação aumentou em três vezes no mesmo período. Tais alterações refletiam o crescimento urbano-industrial brasileiro resultante da política de substituição de importações iniciadas pós-crise de 29 . Nos anos 30 a produção industrial de bens e consumos cresceu e se diversificou de forma importante, e nos anos 40 passaria a uma nova etapa com as iniciativas voltadas a implementação da indústria de base em território nacional (TEIXEIRA \& TOTINI, 1991, p.174). Entre 1940 e 1950 o número de estabelecimentos industriais em funcionamento no Brasil praticamente dobrou, passando de 49.418 para 89.086 pressionando a já incomoda dependência de derivados de petróleo. Os gastos com importação de derivados (combustíveis e lubrificantes) saltaram de 411 milhões de cruzeiros em 1940 para 2 bilhões de cruzeiros em $1950^{28}$.

\footnotetext{
${ }^{27}$ ANP - Consulta de Poços Perfurados. Disponível em http://www.anp.gov.br/?pg=42181\&m=\&t1=\&t2=\&t3=\&t4=\&ar=\&ps=\&cachebust=1398112276795

${ }^{28}$ Informações retiradas do Anuário Estatítico do Brasil, produzido pelo IBGE em 1953, fruto do Recenseamento Geral de 1950 : Produção Industrial, a) Confronto com os dados do Censo Industrial de 1940 (p. 124); Produção Extrativa - Principais produtos da indústria extrativa mineral - 1938/51 (p. 93); Comércio Exterior - Importação - 1938/52 (p. 292). Acessível em: http://biblioteca.ibge.gov.br/visualizacao/periodicos/20/aeb_1954.pdf
} 
Outra questão vital era o refino. No período analisado apenas três refinarias privadas funcionavam no Brasil. O Rio Grande do Sul abrigou as duas primeiras, a Refinaria Riograndense (Destilaria Riograndense de Petróleo S/A) em Uruguaiana, que inicia suas atividades em 1933, iniciativa de investidores brasileiros e argentinos, e a Ipiranga (Ipiranga S/A Cia. Brasileira de Petróleo) no Rio Grande em $1936^{29}$.Neste mesmo ano começam as atividades de refino também em São Caetano do Sul, na refinaria das Indústrias Matarazzo de Energia (COSTA, 2012, p. 101).Somente em 1950 instala-se a primeira refinaria estatal no Brasil, a atual Refinaria Landulpho Alves (RLAM) em Mataripe na Bahia.

As primeiras refinarias privadas brasileiras responderam às decisões locacionais num período de oferta de matéria-prima internacional, o que explica a escolha do extremo sul do Brasil para as primeiras iniciativas, já que Argentina e Uruguai forneciam o petróleo para essas refinarias. A Refinaria Landulpho Alves foi fruto do planejamento estatal, seguindo também o modelo de aproximar a refinaria da fonte de petróleo, resultado do conhecimento das acumulações de petróleo do Recôncavo baiano. A RLAM foi instalada na localidade do Mataripe, no município de São Francisco do Conde, coração do Recôncavo baiano, a aproximadamente 6 quilômetros de Candeias, o principal campo petrolífero do período, às margens da Baía de Todos os Santos ${ }^{30}$. Embora representasse um grande avanço estratégico, a capacidade de refino de Mataripe (2.500 bpd) estava muito aquém das necessidades internas de suprimento do Brasil que eram de aproximadamente 150.000 bpd.

A perspectiva de aumento de dependência energética fomentava ainda mais o imbróglio sobre a gestão do petróleo nacional que dominava a cena política e a sociedade brasileira no final dos anos 40 . Não se tratava de uma discussão apenas econômica, era uma questão de soberania nacional. Ao enviar ao Congresso Nacional, em 1948, o anteprojeto de lei - o Estatuto do Petróleo - que possibilitaria a participação de capital estrangeiro nas atividades de explotação do petróleo brasileiro, Dutra gerava a possibilidade de destruição de todo arcabouço legal relacionado às questões do petróleo (estatizante e nacionalista), construído ao longo do primeiro governo Vargas. Estruturação legal fruto do influente pensamento geopolítico da cúpula militar na defesa dos interesses nacionais e na proteção dos recursos energéticos estratégicos, frente aos interesses das multinacionais do petróleo, onde se destacava a figura do General Horta Barbosa que havia presidido o CNP até 1943. A reação ao Estatuto do petróleo não tardou a surgir.

A tese do monopólio estatal do petróleo brasileiro ganhou força política e adesão popular. A campanha foi iniciada com debates no Clube Militar e organizada pelo Centro de Estudos e Defesa do Petróleo e da

\footnotetext{
${ }^{29}$ A Ipiranga entra em funcionamento em 1937, e trazia participação societária de uruguaios que se juntaram ao mesmo grupo da Destilaria Riograndense. Na verdade há um deslocamento estratégico da atividade de refino de Uruguaiana, localizada no extremos oeste do Rio Grande do Sul, na divisa com a Argentina, e muito próxima do Uruguai, para o litoral no Rio Grande. A intenção era não depender dos portos argentinos que originalmente recebiam petróleo vindo do Equador. Desta maneira a refinaria receberia diretamente o petróleo em um porto brasileiro.

${ }^{30}$ Sobre os impactos territoriais da instalação da Refinaria Landulpho Alves em Mataripe ver a obra de Cristóvão Brito: A Petrobras e a gestão do território no Recôncavo baiano, 2008. Disponível em: http://static.scielo.org/scielobooks/jpst2/pdf/brito-

9788523209216.pdf. Sobre a história da implementação do refino no Brasil ver Pierre Alves Costa:A Cidade do petróleo, 2012.
} 
Economia Nacional (CEDPEN) ${ }^{31}$. Em setembro de 1948, no auge das tensões, o Deputado Artur Bernardes, presidente honorário do CEDPEN, discursava na tribuna do Congresso Nacional em resposta à repressão a uma manifestação pró-tese monopólio estatal:

\begin{abstract}
Sr. Presidente, Srs. Deputados, na qualidade de presidente honorário do Centro de Estudos e Defesa do Petróleo, não poderia deixar de vir, agora, à tribuna, a fim de associar o meu aos protestos aqui levantados contra os acontecimentos que se desenrolaram na madrugada de hoje.Dou à Câmara o meu testemunho de que o Centro de Estudos e Defesa do Petróleo, desde o início, se dispõe a pautar sua conduta dentro da mais estrita observância à lei e do respeito às autoridades. Tomamos a deliberação de defender a tese da nacionalização do petróleo pela convicção de não ser possível que um patrimônio desse valor, indispensável ao progresso futuro da Nação, caia em mãos de estrangeiros, para se locupletarem com o produto do comércio do petróleo.Tive ensejo de conversar a respeito com o Sr. Presidente da República,quando da formação do Centro. S. Ex.a assegurou-me que teríamos complete liberdade para fazer a propaganda que iniciamos, e que vai conquistando a opinião nacional em todo o território do Brasil. Não havia trazido ao conhecimento do plenário as inúmeras manifestações recebidas nesse sentido, por não ser chegado o momento de discutir aqui o anteprojeto. Mas posso assegurar à Câmara que, se houver um plebiscito para decidir a questão, o País, na sua extraordinária maioria, se manifestará a favor do monopólio pelo Estado.

(Deputado Artur Bernardes - Trecho do discurso na Sessão de 24 de Setembro de 1948, Congresso Nacional) ${ }^{32}$
\end{abstract}

De fato, a campanha "O Petróleo é nosso!" exerceu tal influência nos meios políticos e sociais que o anteprojeto acabou por ser arquivado. A tese do monopólio estatal vencera os interesses internacionais dos grandes trustes do petróleo, e com o retorno de Vargas ao poder, pavimentava-se o caminho para a criação da Petrobras em 1953.

O debate sobre o petróleo nacional não estava restrito a uma conjuntura interna, o contexto internacional se modificara intensamente desde o início do século XX, com ingresso de novos atores e acirramento das disputas por suprimento de petróleo.

A reação nacionalista no caso brasileiro não era um caso isolado, desconectado do contexto mundial. Respondia claramente às transformações na escala global, à processos políticos e econômicos implementados no centro do sistema mundial que, por contágio, levaram a uma maior intervenção do estado na economia e na gestão do território também na periferia do sistema, ambiente propício para posições nacionalistas. Duas guerras mundiais, com uma crise financeira sem precedentes com consequências altamente recessivas entre elas, haviam abalado a confiança na doutrina liberal. $O$ atribulado contexto mundial tornou-se oportunidade para que nações como Brasil iniciassem seus processos de industrialização, através da substituição de

\footnotetext{
${ }^{31}$ Associação civil fundada em 21 de abril de 1948, no Rio de Janeiro, inicialmente com o nome de Centro de Estudos e Defesa do Petróleo. Tinha por finalidade básica promover uma ampla campanha de esclarecimentos junto à opinião pública (através de debates, conferências, artigos etc.) voltada para o fortalecimento da tese nacionalista de exploração das jazidas pelo monopólio estatal. Em setembro de 1949 passou a se chamar Centro de Estudos e Defesa do Petróleo e da Economia Nacional. Fonte: http://cpdoc.fgv.br/producao/dossies/FatosImagens/glossario/cedpen.

${ }^{32}$ Discursos selecionados do Presidente Artur Bernardes, Fundação Alexandre Gusmão - MRE, Organização Izabela Medeiros de Souza, 2010.
} 
importações. Nos primeiros 50 anos do século XX houve uma grande expansão geográfica das atividades das grandes companhias privadas de petróleo por todo planeta.

A obtenção de enormes ganhos financeiros não estava mais associada ao querosene para seu uso como iluminante, mas em grande medida, ao papel do petróleo como base para produção de derivados para alimentar motores à combustão, como a gasolina, o diesel, o óleo combustível e o próprio querosene. A necessidade de suprir os sistemas de transporte em geral passou a ser o destino principal do petróleo. A literatura em geral aponta como ponto crucial para introdução do petróleo em outra escala no mundo, a iniciativa do Almirantado Britânico, por intermédio de Churchill, de converter seus navios de guerra para óleo combustível, e não mais carvão (MARINHO JUNIOR, 1970; KATZ, 2008; LOBATO, 2011; YERGEN, 2011, 2012).

O cenário geopolítica do petróleo mundial que no início do século XX estava caracterizado pela competição comercial entre a Standard Oil of Company e a Royal Dutsch Shell, passa a ficar mais complexo, com a entrada de outras companhias petrolíferas, como a britânica Anglo-Persian Oil Company que inaugurara a exploração da região do Oriente Médio, na Pérsia.

Sete grandes empresas petrolíferas dominavam o mercado internacional, e ditavam as suas regras: Standard Oil of New Jersey, Standard Oil Company of New York, e a Standard Oil of Califórnia, Gulf Oil, Texaco, Real Dutch Shell, Anglo-Persian Oil Company. Estas companhias ficaram conhecidas como as "Sete Irmãs"33 e dominavam 92\% do mercado mundial de petróleo. Possuíam as concessões (as reservas), a tecnologia de extração, os meios de transporte, as refinarias, e a rede de distribuição.

Não seria difícil associar que movimentos de independência ao longo do século XX gerariam consequentemente um embate pelo controle da gestão do petróleo no mundo, colocando em rota de colisão os interesses dos grandes trustes do petróleo e projetos nacionalistas de maior controle de suas riquezas naturais.

Foi o que ocorreu no México. Em 1938 o México nacionalizara as empresas de petróleo que atuavam no país. Standard Oil of New Jersey e Royal Dutch Shell dividiam as riquezas petrolíferas mexicanas de forma brutal, negligenciando leis trabalhistas e se recusando a rever contratos de exploração em termos mais igualitários.Tiveram suas empresas expropriadas e nacionalizadas com a criação da Pemex, a Petróleos Mexicanos (GALEANO, 2005).

\footnotetext{
${ }^{33}$ Termo cunhado por Enrico Mattei quando diretor da petrolífera italiana Eni ao criticar o oligopólio praticado pelas companhias. S.O. of New Jersey, S.O. Company of New York, e S.O. of California surgem do desmembramento da S.O. of Company pela Lei AntiTruste nos EUA. O processo de divisão da empresa iniciou-se em 1911. A "filial" de New Jersey que ficou com a metade do valor liquido do truste original. Além destas, surgiram da divisão: S.O. of Ohio, S.O. of Indiana, Continental Oil, e Atlantic. Sobre as outras quatro do grupo das Sete Irmãs: Gulf Oil e Texaco companhias independentes norte-americanas fundadas em 1901; Royal DutchShell (anglo-holandesa, fusão em 1907), e a Anglo-Iranian (antiga Anglo-Persian, britânica, fundada em 1909)
} 
É bem provável que pela proximidade dos eventos, o acontecimento no México tenha reverberado em terras brasileiras quando da descoberta do petróleo em Lobato e exercido certa influência sobre os defensores do monopólio estatal do setor petrolífero, mesmo sendo casos bem distintos. O Brasil ainda buscava o petróleo enquanto no México a produção comercial de petróleo já ocorria desde em 1901. Nos anos 20 o México era responsável pela segunda produção mundial com 190 milhões de barris de petróleo (LOBATO, 2011).

As experiências em países vizinhos municiavam os defensores do monopólio estatal no Brasil. O General Brasileiro Horta Barbosa (então Presidente do CNP) em visita ao Uruguai em 1939 ficou entusiasmado com a refinaria estatal daquele país, a Ancap (Administração Nacional de Combustíveis, Álcool e Portland), que fora fundada em 1931 e que sofrera enormes pressões da Standard Oil (West Indian), Shell, Atlantic e Texaco. (GALEANO, 2005). A criação da Ancap significava o monopólio estatal do refino no Uruguai, e prejudicaria fortemente as empresas internacionais instaladas no país. Galeano faz associação direta entre golpes de Estado e os interesses das grandes corporações de petróleo na América Latina ${ }^{34}$.

Segundo Moniz Bandeira (1998), a América do Sul se transformara em palco de disputa das grandes corporações por reservas futuras de petróleo na primeira metade do século XX, pelo ambiente internacional conturbado. As Revoluções Russa e Mexicana, as disputas entre potências pela pelos antigos territórios otomanos no Orienta Médio e pelos seus campos de petróleo, voltaram os olhares de empresas norteamericanas e da Royal Dutch Shell para o mercado sul-americano. Em 1929 a Standard Oil (através de suas inúmeras filhas) tinha concessões na Colômbia, Venezuela, Peru, Brasil, Bolívia e Argentina, e a Royal Dutch Shell por intermédio da Anglo Mexican também atuava na região, inclusive adquirindo concessões de exploração das extraordinárias reservas em torno do lago Maracaibo na Venezuela, descobertas em 1922. É de fácil conclusão, que o modus operandi das companhias internacionais de petróleo era bem conhecido pelos militares e políticos pertencentes as esferas decisórios no Brasil, bem como as perdas e ganhos de países que concediam suas reservas à exploração estrangeira.

\section{CONSIDERAÇÕES FINAIS}

A partir de 1950 houve uma aceleração das mudanças na geopolítica do petróleo mundial. O processo de descolonização da África, o acirramento da Guerra-Fria, a Crise de Canal de Suez, a centralidade do Oriente Médio, a explosão do consumo de derivados do petróleo, e o surgimento da Organização dos Países

\footnotetext{
${ }^{34} \mathrm{Em}$ sua consagrada obra As Veias Abertas da América Latina, Eduardo Galeano lista uma série de eventos políticos correlacionando-os com a questão do petróleo na América Latina. Como na Argentina em 1930: golpe de estado antes da votação da nacionalização do petróleo; e no Uruguai em 1933: golpe de estado e Ancap perde monopólio da importação de combustíveis. A Guerra do Chaco entre Bolívia e Paraguai entre 1932 e 1935 tinha como um dos seus vetores o petróleo e a interferências dos trustes internacionais do petróleo. Ver “A Guerra do Chaco” de L. A. Moniz Bandeira. Rev. Bras. Pol.Int. 41 (1) (1998).
} 
Exportadores de Petróleo (OPEP), selariam a era de ouro das "Seven Sisters". No Brasil a Petrobras dava seus primeiros passos.

A Lei $n^{\circ} 2.004$ de 3 de outubro de 1953 em seu artigo $1^{\circ}$ encerrava uma década de discussões sobre o funcionamento do setor do petróleo no Brasil, e de forma favorável aos defensores do monopólio estatal. Passavam a ser monopólio da união: as pesquisas e a lavra das jazidas de petróleo e outros hidrocarbonetos fluídos e gases raros existentes no território nacional; a refinação do petróleo nacional ou estrangeiro; o transporte marítimo do petróleo bruto de origem nacional ou de derivados de petróleo produzidos no país, e o transporte, por meio de condutos, de petróleo bruto e seus derivados, assim como de gases raros de qualquer origem. O CNP seria o órgão fiscalizador do monopólio da União, e a Petrobras e suas subsidiárias seriam os órgãos responsáveis pela execução.

Iniciava-se uma nova fase da geo-história do petróleo no Brasil e seus desafios, como a criação de um parque de refino ${ }^{35}$, de um sistema de distribuição, a formação de pessoal qualificado, a internalização de tecnologia, e a descoberta de grandes jazidas de petróleo. As próximas décadas, seriam de desenvolvimento estatizante, de ondas modernizadoras e conservadoras (BECKER;EGLER, 1993), principalmente a partir da década de 60, com a descoberta de grandes acumulações de petróleo em mar, com forte impacto sob o território nacional.

\section{REFERÊNCIAS}

AZEVEDO, A. M. M. de. Regulação ambiental e mudança técnica na indústria de refino de petróleo: o caso da refinaria de Paulínia. 2005. (SN)f. Dissertação (Mestrado em Política Científica e Tecnológica) - Instituto de Geociências, Universidade Estadual de Campinas, 2005.

BRAUDEL, F. Escritos sobre a história. 2 ed. São Paulo: Perspectiva, 2005. Disponível em: <http://historiaempdf.blogspot.com.br/2015/05/braudel-f-escritos-sobre-historia.html>. Acessado em 18 abr. 2016.

BECKER, B. K.; EGLER, C. A. G. Brasil Uma Nova Potência Regional na Economia-Mundo. Rio de Janeiro. Editora Bertrand do Brasil S/A. 1993.

CADENA, N. A primitiva usina de petróleo de um inglês na Bahia no século XIX. Memórias da Bahia. Salvador, 20 Novembro 2012. Disponível em < http://www.ibahia.com/a/blogs/memoriasdabahia/2012/11/20/a-primitiva-fabrica-de-petroleo-de-um-ingles-nabahia-no-seculo-xix/>

CARVALHO, P. R. dos S. O impacto da legislação ambiental na indústria de petróleo brasileira. 2001. 147f. Dissertação (Mestrado em Engenharia de Produção) - COOPE, Universidade Federal do Rio de Janeiro, 2001.

CASTRO, T. África: geo-história, geopolítica e relações internacionais. Rio de Janeiro: Biblioteca do Exército, 1981.

CASTRO, T. Estudos de geo-história. Rio de Janeiro: Record, 1971.

COSTA, P. A. A cidade do petróleo. Guarapuava: Unicentro, 2012.

35 Contando apenas com uma Refinaria estatal - a de Mataripe na Bahia35 - e com produção de 2.663 barris por dia, o Brasil não alcançava nem mesmo $2 \%$ de sua necessidade de consumo interno, que era da ordem de 160 mil barris por dia em 1954. A partir dos anos 80 houve estagnação e posteriormente retrocesso no parque de refino nacional. 
COTTA, P. O petróleo é nosso? Ed. Guavira, 1975.

DIAS, J. L. de M.; QUAGLINO, M. A. A questão do petróleo no Brasil: uma história da Petrobras. Rio de Janeiro: CPDOC, 1993.

GALEANO, E. As veias abertas da América Latina. 45 ed., Rio de Janeiro: Paz e Terra. 2005

KATZ, F. O México: a república restaurada e o porfiriato, 1867-1910. In: BERTHELL, L. (Org.). História da América Latina: de 1870 a 1930, volume V. São Paulo: edusp; Brasília: FUNAG, 2008. p. 23-105.

LOBATO, M. O escândalo do petróleo e o georgismo e comunismo. São Paulo: Editora Globo, 2011.

LUCCHESI, C. F. Petróleo. Estudos Avançados. v.12, n. 33, p.17-40, mai./ago. 1998.

MARINHO JÚNIOR, I. P. Petróleo, política e poder: um novo choque do petróleo? : J. Olympio Editora, 1989.

. Petróleo: soberania e desenvolvimento. Rio de Janeiro: Edições Bloch, 1970.

MILANI, E. J. et al. Petróleo na margem continental brasileira: geologia, exploração, resultados e perspectivas. Brazilian Journal of Geophysics. vol. 18, n. 3, p. 351-396, 2001

MINADEO, R. Um Estudo de História Empresarial: Histórico do Setor Petróleo. 1998. (SN)f. Tese (Doutorado em Engenharia de Produção) - COOPE, Universidade Federal do Rio de Janeiro, 1998.

NEIVA, J. Conheça o petróleo. 5. ed. Rio de Janeiro: Ao Livro Técnico, 1986.

RIBEIRO, G. Fernand Braudel e a geo-história das civilizações. História, Ciências, Saúde - Manguinhos, v.18, n.1, jan-mar, 2011, p.783.

SOUZA-LIMA, W. et al. Bacias sedimentares brasileiras: Bacia de Camamu. Phoenix, Ano. 5, n. 54, jun 2003. Disponível em: http://www.phoenix.org.br/Phoenix54_Jun03.htm

TEIXEIRA, F. M. P., TOTINI, M. E. História econômica e administrativa do Brasil. 2. edição, São Paulo: Ática, 1991.

TELLES, P. C. da S. Antecedentes das histórias do petróleo e das fontes alternativas de energia no Brasil. Boletim Técnico da PETROBRAS, Rio de Janeiro, v. 29, n. 6, p. 253-258, jul/set. 1986.

VAITSMAN, M. O petróleo no Império e na República. 2. ed. Rio de Janeiro: Interciência, 2001. O petróleo no Império e na República. Rio de Janeiro: Empreza Gráfica “O Cruzeiro”, 1948.

VIANNA, F. V.; FERREIRA, J. C. Memoir of the State of Bahia. Salvador: Arquivo Público do Estado da Bahia, 1893.

YERGIN, D. A busca: energia, segurança e a reconstrução do mundo moderno. Rio de Janeiro: Editora Intrínseca, 2011.

YERGIN, D. O Petróleo: uma historia mundial de conquistas, poder e dinheiro. São Paulo: Paz e Terra, 2012. 1.080p. 